\title{
Performance of the Microfinance Investment Vehicles
}

\author{
Erwan Le Saout ${ }^{1,2}$ \\ ${ }^{1}$ PRISM Sorbonne, University Paris 1 Panthéon-Sorbonne, France \\ ${ }^{2}$ Labex REFI, France \\ Correspondence: Erwan Le Saout, 17 rue de la Sorbonne 75231 Paris Cedex 5, France.
}

Received: August 9, 2017

Accepted: October 16, 2017

Available online: October 22, 2017

doi:10.11114/aef.v4i6.2719

URL: https://doi.org/10.11114/aef.v4i6.2719

\begin{abstract}
Over the last few years, the microfinance sector has seen its transformation. Microfinance institutions seek a wide range of sources of funding, while private investors seek not only social returns but also financial returns. This new approach has led to the emergence of microfinance investment funds and initial public offerings of certain Microfinance institutions. Microfinance now seems to be seen as a new investment opportunity by global investors.

Aim of this paper is to study the performance of public Microfinance Investment Vehicles. Despite a significant currency risk, we find that the integration of microfinance assets diversifies the investor's risks and improves the efficient frontier. We conclude that microfinance institutions, via investment vehicles, are likely to attract capital from socially responsible investors seeking new investment opportunities despite a sharp decline in the Sharpe ratio over the past few months.
\end{abstract}

Keywords: financial markets, microfinance investment vehicle, performance, spanning tests

JEL classification codes: G11, G21, G23, O16

\section{Introduction}

Microfinance refers to the provision of a broad range of financial services that target poor households, particularly women, and small enterprises that do not have access to formal financial institutions. Microfinance spans a range of financial instruments including loans, deposits, savings, insurance, remittances, payment services, insurance services, mortgages and retirement plans. The diversity of products and services offered reflects the fact that the financial needs of individuals, households, and enterprises can change significantly over time, especially for those who live in poverty. Because of these varied needs, and because of the industry's focus on the poor, microfinance institutions often use non-traditional methodologies, such as group lending or other forms of collateral not employed by the formal financial sector. All of these services are offered in small amounts, making them accessible to individuals previously shut out from formal means of borrowing and saving (Khavul, 2010). Microfinance also provides social intermediation that involves organizing citizens' groups as a venue to voice their aspirations, raise concerns for consideration by policy makers and develop their selfconfidence (Ledgerwood, 1999). Microfinance institutions offer skill-based training programs to augment the productivity and organizational support and to provide consciousness-raising training to empower the poor. Thus beyond the objective of providing financial services to the poor, the microfinance institution have the ambition to help alleviate poverty.

In recent years, the microfinance sector has grown in number and in volume and has been going through profound changes. It is being increasingly criticized, namely the incentives of microfinance providers. Microfinance activities are currently performed through a diverse array of institutions such as public and private banks and non-governmental organizations (NGOs). Poverty reduction no longer appears to be the main focus of Microfinance institutions (MFIs) that evolved from a community of donors led by philanthropic goals to a rapidly growing market that attracts investors seeking a financial performance. Morduch (2000) refers to this cleavage as the microfinance schism. Numerous regional and international banks are tapping into the microfinance market trying to achieve this double bottom line or only the second one. More and more institutions are eager to become financially sustainable and subsidy-free. A financially profitable and sustainable MFIs is likely to find financial resources for its needs and growth, easier than MFIs seeking to maximize their social impact instead. This new approach has led to the emergence of microfinance investment funds and IPO of certain institutions. This is an illustration of commercialization that Halpern (2000) defined as the application of market principles to microfinance. We have entered into the final stage of microfinance commercialization that "begin when microfinance attracts a significant number of pure private investors, whose investments are motivated by the MFI's 
profit potential, to become shareholders of commercial MFIs".

This article is a contribution to a recent restricted literature dealing with the return of microfinance investment in the financial markets. According to Swanson (2008), given the significant growth of MFIs that seek for a wide and diversified range of funding sources, capital markets will take an increasingly important share in the financing. At first sight, this would undoubtedly contribute to the financialization of the industry. Analyzing the performance of microfinance seems pertinent when socially responsible investors are seeking new investment opportunities respecting "double bottom line" returns. Indeed, microfinance investment vehicles have a wide range of characteristics of social and financial performance.

This paper is organized as follows. In the first part, we present recent developments of microfinance and their protagonists. The second part deals with the performance of microfinance in capital markets. The third part aims to provide comprehensive analysis on microfinance investment vehicles. The fourth part presents an empirical analysis of the performance of microfinance investment vehicles. Lastly, we conclude and suggest area of further research.

\section{What Is Microfinance?}

The demand of microfinance services consists of two types: in the one hand, the income generating activities, and in the other hand, the small enterprises. The income generating activities are defined as non-permanent activities, like an individual owning a retail shop or a micro-service provider. The small enterprises are of two types: microenterprises, composed of one entrepreneur assisted or not by his family members, and small enterprises, composed of a few number of employees supervised by an entrepreneur. On the supply side, the microfinance offer has evolved to take into account the growing demand. MFIs have expanded the range of products and services, from providing only microcredit - group lending and individual lending - and savings, to include more services and reach a wider market of unbanked and under-banked clients. The new offer embraces financial and non-financial services. The financial services involve micro-insurance, housing credits, transfer of funds, and remote financial services. The non-financial services include the development support services, as technical trainings, trainings in marketing and in management, and the social services, as providing services in education, healthcare, nutrition, and illiteracy eradication. According to Brau and Woller (2004), MFIs providing non-financial services, in addition to its financial offer, have a better performance in comparison with microfinance organizations that provide only financial services, known as minimalists.

Historically, microfinance providers are NGOs, whose principal aim is to help shifting people from poverty. They focus particularly on the very poor and on female borrowers, who live mostly in rural or distant areas. Since their establishment and along their growth, they benefit of grants and subsidies from private foundations, governments, international aid agencies and even individual donations. NGOs are not-for-profit institutions that are obliged to reinvest every penny gained from its operations within the institution. Though, since it targets the riskiest class of poor people, it is not likely to generate high profits. Credit unions and cooperatives constitute another form of not-for-profit microfinance institutions. They are mostly present in villages and rural communities. Their members make deposits into the institution in order to be able to contract a loan. Again, all the benefits from operations are reinvested within the institution. A growing number of not-for-profit microfinance institutions are registering to a regulated legal form, principally for two reasons. The first reason is the development of the sector accompanied by an increased scarcity of funding sources and more exigent funders. The second reason is the high returns that can be potentially achieved with a registered for-profit legal form. Commercial banks constitute the broad type of profit-seeking microfinance institutions. They provide the larger range of microfinance products and services to the poor. In addition to micro-loans, banks offer savings accounts, money transfers, exchange services, and micro-insurance. Rural banks are banks established in rural areas where clients are mainly farmers, fishermen, artisans or shopkeepers. They provide their clients with tailored financial services, in particular individual loans and group loans. Non-banking financial institutions are financial intermediaries similar to banks but do not hold a banking license because of their lack of capital requirements, or their limited offer of financial services, or simply because they are not regulated institutions.

Profit-seeking microfinance institutions are generally operationally and financially self-sufficient. Those holding a bank legal form have access to funds from external global markets. Besides, they tap into deprived populations that are denied access to traditional banking services but still have the means to contract and pay back a small loan or even to make deposits on a savings account. In addition to servicing the "moderately" poor, such institutions maximize their profits through imposing relatively high interest rates and deploying intensive efforts to extract loan settlements from their clients. The behaviour of some profit-seeking microfinance institutions such as Compartamos bank has been largely criticized. The microfinance industry worldwide has encountered some struggles during the period that followed the declaration by the United Nations of the year 2005 as The International Year of Microcredit. Microfinance products, namely microcredit, have been criticized for their relatively high returns. MFIs enjoy a much higher interest rate policy than conventional commercial banks, which leads to questioning about the fairness of these prices in the context of lending to the poor (Hudon and Ashta, 2013). Other criticisms portrayed MFIs as exploitative. The Andhra Pradesh 
crisis has pointed at the predatory behavior of some Indian MFIs, ever since dubbed micro-sharks, which were accused of deploying patriarchal norms to extract loan settlements from their clients. Moreover, MFIs' will to improve their financial performance is considered, by the advocates of the welfarists' approach, as the reason behind their increasing interest rates and their determination to enhance their loan repayment rates. Fitting to this approach, the profit-seeking goal of MFIs conflicts with the goal of poverty alleviation. According to Christen (2001), Institutionalists, viewed as advocates of the opposite approach, argue that microfinance will not be efficient towards poverty reduction unless MFIs improve their financial performance.

Meehan (2004) suggested a segmentation of the specialized microfinance institutions that focus exclusively on the microfinance sector. Microrate, a microfinance rating agency, recalls and adapts this segmentation. Henceforth they propose a tier system that defines MFI peer groups by institutional maturity to provide a foundation for industry analysis and informed dialogue. The system is based on a three-tier structure, which applies three indicators that act together as proxies for MFI maturity. The three indicators are sustainability, size and transparency. Table 1 reports tier definitions. Tier 1 is composed of the most regulated, mature, large, commercially-oriented and thus profitable MFIs. According to Meehan (2004), MFIs of tier 1 attract the interest of local and global commercial banks, as well as savings and credit cooperatives and postal banks. The intention of a growing number of MFIs, mainly those of tier 1, is to improve their financial performance by becoming more operationally and financially efficient and self-sufficient. Tier 2 includes small or medium sized, slightly less mature MFIs that are, or are approaching, profitability. Tier 3 is quasi totally composed of NGOs and Start-up MFIs. They are immature and unsustainable.

This system leads to the pyramidal structure. According to Microrate, the tier 1 includes $7 \%$ of total MFIs, the tier 2 includes $23 \%$ of total MFIs, while the tier 3 of the pyramid represents $70 \%$ of the sample. Beyond these figures, it should be noted that in recent years the base of the pyramid has narrowed. This is explained by the development of MFIs' activities. This development is possible only if MFIs attract new sources of financing. The refinancing of MFIs depends on their stage of development. The more mature the MFI is, the more it expands its financing resources. MFIs that have a goal of financial performance are likely to seek financing through local and international capital markets, capital increases and deposit accounts whereas for NGOs, resources are often limited to donations and supranational funding.

Table 1. Tier Definitions

\begin{tabular}{|c|c|c|c|}
\hline & Tier 1 & Tier 2 & Tier 3 \\
\hline Performance & $\begin{array}{c}\text { (i) Positive RoA for at } \\
\text { least } 2 \text { of the last } 3 \text { years } \\
\text { AND } \\
\text { (ii) No RoA <-5\% in the } \\
\text { last } 3 \text { years }\end{array}$ & $\begin{array}{c}\text { (i) Positive RoA for at } \\
\text { least } 1 \text { of the last } 3 \text { years } \\
\text { and other years> } 5 \% \\
\text { OR } \\
\text { (ii) Positive trend in RoA } \\
\text { in last } 2 \text { years and }>5 \%\end{array}$ & The rest \\
\hline Size & $>$ USD 50 millions & $\begin{array}{c}\text { USD 5 - USD } 50 \\
\text { millions }\end{array}$ & $<$ USD 5 millions \\
\hline Transparency & $\begin{array}{l}\text { (i) Regulated financial } \\
\text { institutions } \\
\text { OR } \\
\text { (ii) Rated at least once in } \\
\text { the last } 2 \text { year }\end{array}$ & $\begin{array}{c}\text { Audited financial } \\
\text { statements for at least the } \\
\text { last } 3 \text { years }\end{array}$ & The rest \\
\hline
\end{tabular}

Source: MicroRate

\section{Performance of Microfinance in Capital Markets?}

Microfinance has witnessed a spectacular expansion after the attribution of a Nobel Peace Prize to Muhammad Yunus and the Grameen Bank in 2006. Donors' fund did not be enough to back the growth of the microfinance institutions. The evidence that microfinance can be profitable alongside the need for large amounts of funding imply that the financing of microfinance will increasingly be supplied by commercial sources. In this context, some microfinance institutions chose to convert into regulated for-profit private equity companies to access new funding sources and increase their profitability. Faced with such situation, the most successful ones took the plunge to tap into capital markets. They attract global investors especially through initial public offering. We may cite the examples of Banco Compartamos in Mexico and SKS in India. These companies had been widely criticized at the time but the success of their IPO had enabled them to achieve an international dimension reinforced by high initial returns.

To date, few studies have been carried out to examine the financial performance of microfinance in financial markets, probably due to the young age of this market. Most of the studies conclude that microfinance is an appropriate investment opportunity for portfolio diversification. Oehri and Fausch (2008) examine the economic impact of microfinance investment funds and their return/risk profiles. The authors build sample portfolios consisting of different assets and define three investment strategies dependent on investors' risk profile: "defensive", "balanced" and "growth". They alter the composition of the portfolio by adding a variable percentage of microfinance investment funds. Oehri 
and Fausch (2008) highlight that "Investment in microfinance funds can be considered a favorable investment independent of the current market situation. Substitution with money market investments contributes to improvements in portfolio performance regardless of the market situation". These results cannot be generalized because, as the authors point out, the performance varies by region (Daher and Le Saout, 2013).

Dominice et al. (2014) analyze the performance of the SMX-MIV Debt USD index over the period 2003-2011. This index created by the company Syminvest tracks on a monthly basis, the net asset value of a selection of funds with a majority of assets invested in fixed income instruments. According to the authors, the risk-return profile of the SMX-MIV Debt index shows a 55\% correlation with money markets. Volatility is similar but the yields are higher. This leads to a more favorable Sharpe ratio particularly during the financial crisis when the Libor rate declined sharply. Dominice et al. (2014) suggest that including the SMX index in a traditional portfolio could have positive effects thanks to very low correlation with other assets. These results are consistent with those of Becker (2010) who analyzes the behavior of microfinance investment funds. The author especially emphasizes the low volatility of these funds.

To investigate the usefulness of the integration of microfinance portfolios, Becker (2010) adopts a qualitative approach. Based on several scenarios, the author simulates the likely behavior of different assets class including investments in microfinance. According to Becker (2010), integrating the results of the scenario analysis of microfinance within a framework of asset allocation shows microfinance debt securities offer a very low level of attractiveness, especially for risk-averse investors. The author recommends a maximum exposure of $5 \%$ in microfinance debt. The author concludes that microfinance debt improves the return/risk ratio of an investment portfolio and moves the efficient frontier slightly to the left. This study also highlights the dependence of the results on the variation of the exchange rates of local currencies, which can be very fragile, especially during financial crises.

Janda and Svarovska $(2010,2012)$ conducted case studies. The authors analyze the investment performance of microfinance investment mutual funds and their sub-funds. Authors observe that during this period funds have a lower total risk than global stocks and bonds with moderate but stable returns. The authors interpret their results as demonstrating that investment in microfinance investment funds represents an attractive opportunity to reduce the overall risk of a portfolio. Indeed, according to the authors, microfinance investment vehicles do not show any positive correlation with global or emerging capital markets. Janda and Svarovska (2010) also conclude that MIVs do not reach any added returns above those returns that compensate an investor for an identical risk measured by the beta. Janda and Svarovska (2012) analyze also the relationship between microfinance funds' returns and the performance of stock and fixed income markets in developed and emerging economies. Using Jensen's Alpha and mean-variance spanning test, Janda and Svarovska (2012) accept two hypotheses. The first one consider that returns on investment in microfinance investment funds are not positively correlated with returns on a market portfolio. The second one states that returns on investment in microfinance investment funds exceed the returns on a market portfolio.

J.P. Morgan has created a market cap-weighted index: the LIFI (Lower-income financial institutions) Index. This index encompass various geographical regions and business models (De Mariz et al., 2012, 2013). The LIFI Index has significantly outperformed the MSCI World Financials Index and the MSCI EM Banks Index since its inception in November 2003 and over different periods. The correlation of the returns of the LIFI Index to the returns of the MSCI EM Banks Index has been 66 percent on average since November 2003. The correlation between the two indices decreased meaningfully in the second half of 2011, reaching a low of 41 percent, and is back to average levels of 89 percent in 2012. According to De Mariz et al. (2013), this was mostly due to the LIFI Index being relatively resilient to global turmoil (U.S. rating downgrade and European sovereign crisis). Brière and Szafarz (2015) evaluate the profitability of investing in microfinance via stock markets. The authors build microfinance indices: one microfinance index per country and one global microfinance index. Authors found that investing in microfinance is very profitable, since as of December 31,2010, the majority of listed microfinance institutions have high returns. Brière and Szafarz (2015) found that starting in 2001, the correlation between financial markets and listed MFIs has increased. This suggests that MFIs, especially those listed on a stock market, are becoming more like commercial banks. Nevertheless, according to De Mariz et al. (2013), listed microfinance institutions have a discount around 15\% compared to traditional commercial banks depending on the multiple capitalization retained. Regarding risk, analysis based on the CAPM leads to a higher sensitivity of MFIs. In contrast, exposure to currency risk is similar for both types of assets. Brière and Szafarz (2015) conclude that there is a reduction of the effect of MFI diversification. Daher and Le Saout (2017) highlights the contribution of microfinance investments in portfolio diversification is not significant. Their analysis is based on the classic indicators of performance measurement (Sharpe and Treynor ratios) and spanning tests. MFIs nevertheless may be a good alternative to investing in emerging financial shares. The authors also note that the performance of a diversified portfolio is not affected by such investments. In recent years, there has been no financial sacrifice to invest in microfinance. Furthermore, Daher and Le Saout (2017) observed persistent low correlation to equities and bonds. Contrary to what could portend the outcome of Brière and Szafarz (2015), the author notes that the correlations found their low level before the crisis. Le Saout and Daher (2016) empirically explored weak efficiency of 
listed microfinance institutions. Their results show that microfinance companies are significantly weak form efficient, suggesting no excess returns over time through speculation. This outcome is not necessarily the case for the small capitalizations where the random walk hypothesis is rejected notably because of a lack of liquidity according to Le Saout and Daher (2016). According to the authors, efficient market hypothesis may serve as an instrument to convince sustainable asset funds to invest in listed microfinance providers.

\section{Microfinance Investment Vehicles}

Microfinance investment vehicles are funds or structured products that provide debt obligations or take equity stakes in microfinance institutions. They are an important funding instrument of MFIs. There are several types of funds whose objective is not only to achieve financial performance but also to achieve social performance. Dieckmann (2007) distinguishes three types of MIVs. First, microfinance development funds act as non-profit entities or cooperatives and primarily target the development of MFIs by granting capital at favorable financial conditions without necessarily seeking a financial return. Second, dual-objective microfinance or commercially-oriented microfinance investment vehicles aim to strike a careful balance between social and financial returns. Third, commercial funds have a predetermined financial target rate of return while social returns play a secondary role. According to Luminis Microfinance, for a fund to qualify as an MIV, it must meet the following three criteria:

- The investment vehicle must be an independent and legal entity for raising and investing funds (i.e., independent of the MFI being funded);

- Multiple private investors must be present, or the vehicle must be open to such investors; and

- The investment vehicle must focus on investing in microfinance.

Analyzing the performance of microfinance investment vehicles is a difficult challenge. Indeed, the market is not very expanded. In 2016, the MIV Market is composed of about 120 MIVs with over US \$11.6 billion in total assets under management. Another difficulty arises from the very large variety of funds. MIVs vary widely in their structure, investment style, and geographic concentration. Some of them include also non-microfinance assets. Tables 2 to 4 illustrate peer group analysis. Fixed Income remains the lead strategy in terms of investment volumes. Their combined assets still account for nearly three-fourth of the MIVs. Regional exposure in Eastern Europe and Central Asia are the prime region for microfinance investments but exposure decreased last years. We may explain this phenomena by market difficulties encountered in Russia spread in neighboring countries. Mixed Funds exhibit the most diversified regional concentration of all three peer groups.

Following CGAP (2010), we can classify the universe of MIVs according to the 4 following fund types:

- Fixed-Income MIVs - Investment funds and vehicles of which the core activity, defined as greater than 85 percent of their total noncash assets, is to invest in debt instruments.

- Equity MIVs - Investment funds and vehicles of which the core activity, defined as greater than 65 percent of their total noncash assets, is to invest in equity instruments.

- Hybrid MIVs - Investment funds and vehicles that invest in both debt and equity, with greater than 15 percent and less than 65 percent of their total noncash assets invested in equity investments.

- Structured MIVs - CDOs offer a range of asset-backed securities with different risk and return profiles to investors.

Table 2. Geographical allocation

\begin{tabular}{lcccc}
\hline & Equity & Mixed & Fixed Inc. & All Mivs \\
\hline Eastern Europe \& Central Asia & $4 \%$ & $25 \%$ & $40 \%$ & $34 \%$ \\
Latin America \& Caribbean & $41 \%$ & $32 \%$ & $28 \%$ & $30 \%$ \\
East Asia \& Pacific & $7 \%$ & $17 \%$ & $11 \%$ & $11 \%$ \\
South Asia & $40 \%$ & $12 \%$ & $9 \%$ & $12 \%$ \\
Middle East \& Norht Africa & $1 \%$ & $2 \%$ & $3 \%$ & $3 \%$ \\
Sub-Saharan Africa & $7 \%$ & $12 \%$ & $9 \%$ & $10 \%$ \\
\hline
\end{tabular}

Table 3. Total asset composition by peer group

\begin{tabular}{lccc}
\hline & Microfinance & Liquidities & Other assets \\
\hline Equity & $80 \%$ & $8 \%$ & $12 \%$ \\
Mixed & $81 \%$ & $17 \%$ & $1 \%$ \\
Fixed Income & $77 \%$ & $13 \%$ & $10 \%$ \\
All MIVs & $78 \%$ & $13 \%$ & $9 \%$ \\
\hline
\end{tabular}


Table 4. MIV's Allocation

\begin{tabular}{lcccc}
\hline & Public fund & Private fund & Other vehicles & Total \\
\hline Equity & $0 \%$ & $9 \%$ & $1 \%$ & $10 \%$ \\
Mixed & $2 \%$ & $10 \%$ & $4 \%$ & $16 \%$ \\
Fixed Income & $8 \%$ & $47 \%$ & $19 \%$ & $74 \%$ \\
\hline
\end{tabular}

Results concerning MIVs' performance results should be examined in hindsight. The sample size is usually low. Periods of study are often restricted and correspond to a period characterized by successive financial and banking crises. Moreover, the composition of many funds does not seem transparent. Benchmarks used - usually equity indices - do not seem appropriate because the funds are mostly invested in loan agreements and corporate bonds with short maturities. Performance of some funds reflects also the choice of hedging instruments. Indeed, part of investments in debt and in capital are made in the currency of the microfinance institutions. A depreciation of such currency leads to a reduction in the investments' return and entails an increased default risk.

\section{Empirical Analysis}

The purpose of this part is to analyze the performance of Microfinance Investment Vehicles (MIVs). First we present different methodological elements. Thereafter, we present our results.

\subsection{Methodology}

The main difficulty faced by researchers is that the composition of the microfinance vehicles is often opaque. Indeed, the majority of the MIVs are private placement funds, i.e. investment funds and vehicles that raise money from qualified investors through private placements and may or may not be supervised by their local financial authority, as shown in Table 4. We extract from Bloomberg, Net Asset Values (NAVs) of microfinance investment vehicles. We obtained data for 68 funds from January 2008 to June 2017 (114 months). To avoid duplication (there are some sub-funds) and after removing the funds that do not report NAVs on at least a monthly basis, we construct a microfinance fund's portfolio composed of 19 funds. Appendix A reports the components of our portfolio, which includes fixed income funds or mixed funds (no equity funds). Portfolios are intended to grow overtime as more MIVs are created. We assume that the microfinance portfolio behaves as an equally weighted index. Due to monthly price movements of the stocks within the index, the weights will shift and exact equality will be lost. The portfolio must be constantly re-balanced to keep the positions in each stock equal to each other.

$$
M I V_{E W, t}=M I V_{E W, t-1} \times \frac{\sum_{j=1}^{N} N A V_{j, t} \times C_{j, t}}{k_{t} \times \sum_{j=1}^{N} N A V_{j, t-1} \times C_{j, t-1}}
$$

with $\mathrm{t}$ the day of calculation, $\mathrm{N}$ the number of constituent funds in the portfolio, $k_{t}$ the "adjustment coefficient for base capitalization" on day t, $N A V_{j, t}$ and $C_{j, t}$ are respectively the net asset value in USD and the weight of the fund $\mathrm{j}$ at time t. This means that we take into account the exchange rate risk for international investors.

\subsubsection{Risk Adjusted Return}

The portfolio rate of return is calculated using the monthly return of each constituent in USD currency. To estimate the risk-adjusted performance of our portfolio, we retain the most commonly statistics in performance analysis: the Sharpe ratio. This ratio is defined as the ratio of the excess expected return to the standard deviation of return. The aim of this ratio is simply to examine the situations in which two measures (mean and variance) can be usefully summarized by one ratio :

$$
S_{P}=\frac{R_{P}-R_{f}}{\sigma_{P}}
$$

where $R_{f}$ is the Libor 3 months.

The Sharpe ratio tells us whether a portfolio's returns are due to smart investment decisions or a result of excess risk. This measurement is useful because although one portfolio can reap higher returns than its peers, it is only a good investment if those higher returns do not come with too much additional risk. The greater a portfolio's Sharpe ratio, the better its risk-adjusted performance has been.

In order to evaluate the performance of microfinance investment vehicles, we compare them to the following benchmarks:

- $\quad$ The LMI (Listed Microfinance Index) built by Daher and Le Saout (2017). It is a weighted capitalization index 
with a capping ${ }^{1}$ factor. This index comprises 19 listed companies from the microfinance sector. These companies principally operate in Africa and Asia .

- The MSCI Emerging Markets Index (MSEM) is a free float-adjusted market capitalization index that is designed to measure equity market performance of emerging markets. The MSCI Emerging Markets Index consists of 21 emerging market country indices.

- The MSCI World Index (MSWO) is a free float-adjusted market capitalization weighted index that is designed to measure the equity market performance of developed markets. The MSCI World Index consists of 24 developed market country indices.

- The EMBI+ is a market capitalization-weighted index. The EMBI+ tracks returns for actively traded external debt instruments in emerging market, and is also J.P. Morgan's most liquid U.S-dollar emerging markets debt benchmark. The index segments further the universe of emerging markets as defined by the broader EMBI Global and EMBI Global Diversified, by placing a strict liquidity requirement rule for inclusion

- A blended index which performance is equal to 85\% performance of EMBI+ and 15\% performance of MSEM. Most of mixed funds have invested close to $15 \%$ total assets in equity. This explains why we propose a benchmark that combines the performance of bond and equity markets in emerging countries.

Table 5 presents summary statistics for the monthly funds and benchmarks' returns calculated as the first differences in the logs of the funds' net asset values.

Table 5. Descriptive statistics of monthly returns

\begin{tabular}{lccccc}
\hline & MIVs & LMI & MSEM & MSWO & EMBI+ \\
\hline Mean & $0.059 \%$ & $0.087 \%$ & $-0.176 \%$ & $-0.306 \%$ & $0.558 \%$ \\
Median & $0.318 \%$ & $0.964 \%$ & $0.022 \%$ & $0.253 \%$ & $0.651 \%$ \\
Maximum & $4.818 \%$ & $25.016 \%$ & $20.085 \%$ & $22.566 \%$ & $8.726 \%$ \\
Minimum & $-4.446 \%$ & $-42.204 \%$ & $-29.665 \%$ & $-30.946 \%$ & $-13.987 \%$ \\
Std. Dev. & 0.015 & 0.091 & 0.072 & 0.0811 & 0.0271 \\
Skewness & -0.207 & -0.877 & -0.483 & -0.740 & -1.396 \\
Kurtosis & 4.189 & 6.937 & 5.439 & 5.642 & 9.732 \\
\hline
\end{tabular}

We shall discuss later the profitability. The most important fact concerns the volatility. The volatility MIVs portfolio is significantly lower than the bond and equity benchmarks. This is not surprising (Becker, 2010). It is the main objective looked for by asset managers whom we interviewed. The maturity of the investments is weaker than that of the bonds composing the EMBI + index. Besides, the part invested with funds in equity is realized on unlisted companies due to market volatility. This means that the net asset value is not marked to market, but marked to model.

\subsubsection{Spanning Tests}

To test for the existence of diversification benefits related to investing in microfinance investment vehicles, we apply a mean-variance spanning approach, first applied by Huberman and Kandel (1987). Authors test whether adding a new set of risky assets allows investors to improve the minimum variance frontier derived from a given set of risky assets. Following Huberman and Kandel (1987), we say that a set of K risky assets spans a larger set of N + K risky assets if the minimum-variance frontier of the $\mathrm{K}$ assets is identical to the minimum-variance frontier of the $\mathrm{K}$ assets plus an additional $\mathrm{N}$ assets. The first set is often called the benchmark assets, and the second set the test assets. The methodology developed by Huberman and Kandel (1987) has generated various extensions including short sales constraints and number of risky assets in the portfolio ${ }^{2}$. The test gives an answer to the question whether the investor can significantly improve his portfolio by investing in microfinance funds. In other words, from a mean-variance frontier point-of-view, adding assets to the current portfolio will lead by definition to a shift of the frontier. A rejection of the spanning test means that this shift is statistically significant. The spanning test compares the whole set of efficient indexes and tests whether the addition of the other set of MIVs gives significantly better portfolios. In this study, we consider short sale restrictions. It involves that it is not allowed to borrow funds in expectation of a fall in the assets' net asset value.

To complete our analysis, we implement three spanning tests: the test based on the likelihood ratio test provided by Huberman and Kandel (1987) and two tests based on the Wald and Lagrange multiplier principles provided by Kan and Zhou (2012). Insofar as our MIVs portfolio consists mainly of investment in debt, we use as a benchmark asset a composition of three bond indices. These bond indexes are: JP Morgan EMBI+, JP Morgan EMBI diversified and JP Morgan Emerging Markets Bond. Our benchmarks do not include risk-free asset. Our equally weighted portfolio MIVs represents our test assets.

\footnotetext{
1 According to Le Saout (2005), a capped index prevents one action exerts a disproportionate influence on an index.

2 See de Roon et al. (2001) and Kan and Zhou (2012) for literature.
} 


\subsection{Results}

Figure 1 illustrates the cumulative returns of MIVs over the period 2008-2017. The profitability of MIVs is better than the EMBI + and the blended index. We cannot really learn as far as the levels of risk differ. MIVs portfolio invested mainly in debt seems to be less affected by the financial crisis in 2008. However, the reading of the graph lets appear different performances during the period under study. This is why we will examine the performance and benefits of diversification over two subperiods: the first subperiod covers the years 2008 to 2013 while the second sub-period covers the years 2013 to 2017.

Estimates of Sharpe's ratios confirm our perception in figure 1. While over the first sub-period, the performance is positive, it becomes negative between 2013 and 2017. This is an even worse performance of the indices studied. On the whole period, the performance is even considered as negative compared with the risk-free rate. It is lower than the LMI index compound of listed microfinance companies. It may be interesting in the future for asset managers to integrate this type of asset into their portfolios. This could certainly increase the volatility of the fund but it would certainly improve the fund's liquidity as well as the transparency on the equity valuation of the fund. Anyway, let's not forget that there are many types of microfinance whose aim is not only to achieve financial performance but also to achieve social performance.

In order to complete our analysis, we perform regression-based tests for mean-variance spanning in order to detect the effect of investing in microfinance vehicles on the minimum variance frontier.

First of all we interest us at the level of correlation between microfinance vehicles and other stock market indices. Tables 7 report the correlation matrix. we find that the performance is weakly correlated to our benchmark even the index of listed microfinance companies. As mentioned earlier, this is not surprising since asset managers invest only in private equity and not in the listed microfinance companies. The decrease in the correlation during the study period cannot lead to any real conclusions. Indeed, all correlations between indices decline. It is a phenomenon which is systematically observed after the financial crises. Unlike Svarovska and Janda (2012), the correlation coefficients are not negative. This result is not surprising because we believe it seemed implausible that funds which are invested on average $80 \%$ in microfinance assets (thus invested up to $20 \%$ in traditional assets) can have negative betas and correlation coefficients. Probably, these conflicting previous findings were due to specific characteristics of the examined sample, such as the short study period and the small sample size.

Then, we apply a mean-variance spanning approach to test for the existence of diversification benefits related to investing in microfinance investment vehicles. Table 8 presents the probability (P-Value) of rejection of the three spanning tests (Likelihood ratio, Wald test, Lagrange Multiplier): whatever the test, spanning is rejected. The rejection of the spanning hypothesis exhibits that gains in portfolio efficiency can be achieved through diversification. Futher research should investigate the source of the diversification benefits related to investing in microfinance. Following Roon et al. (2001), we should decompose the spanning test in two parts: one related to the tangency portfolio, and the other to the global minimum variance portfolio. The results mitigated at the end of the study period suggest that the downward trend in the Sharpe ratio is a possible explanation.

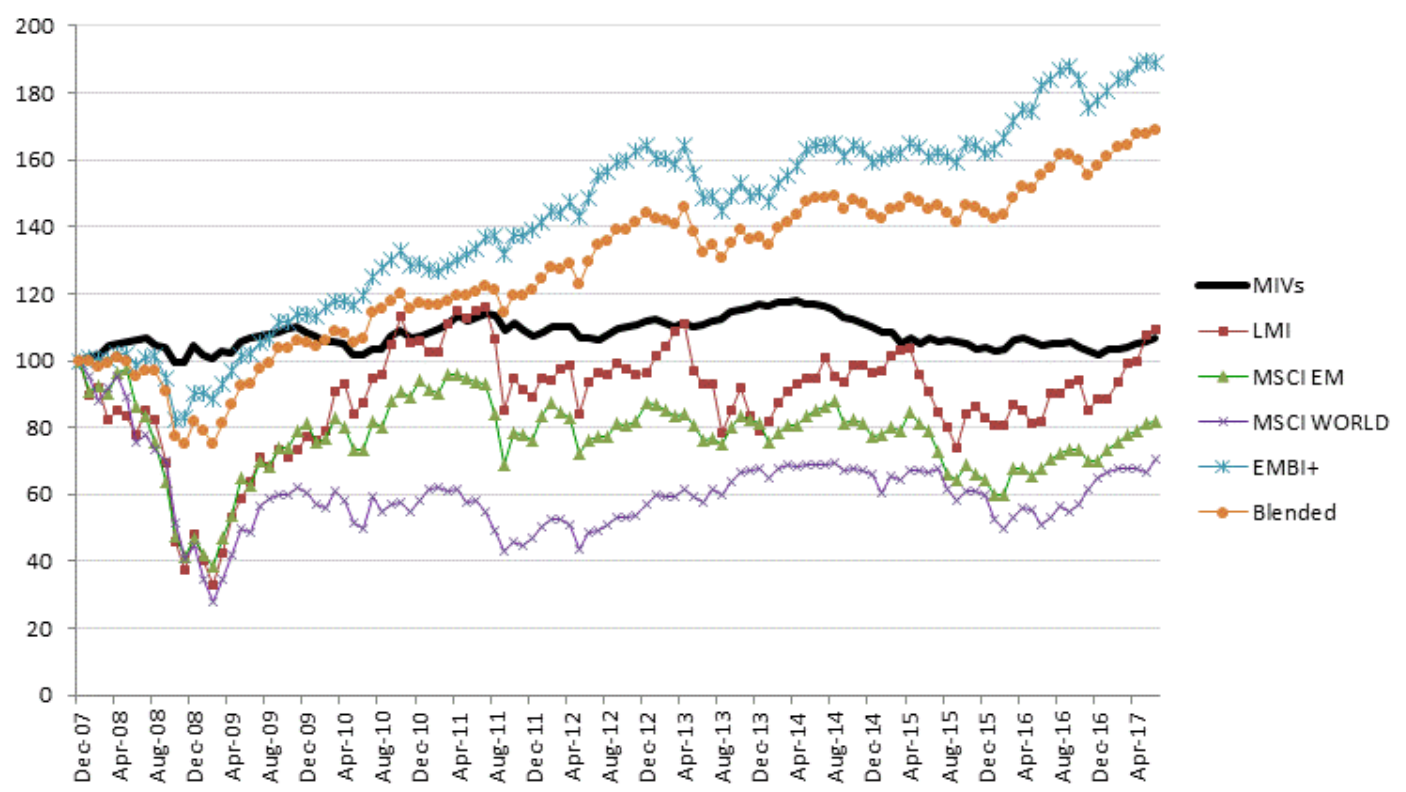

Figure 1. Comparative evolution of microfinance funds index and benchmarks (2008-2017) 
Table 6. Estimations of Sharpe ratios (monthly returns 2008-2017)

\begin{tabular}{cccccc}
\hline MIVs & LMI & MSEM & MSWO & EMBI+ & Blended \\
\hline \multicolumn{7}{c}{$2008-2013$} \\
\hline$-14 \%$ & $-1,77 \%$ & $-5,75 \%$ & $-9,40 \%$ & $16,15 \%$ & $8,88 \%$ \\
\hline$-12,663 \%$ & $1,953 \%$ & $-3,605 \%$ & $6,011 \%$ & $12,617 \%$ & $13,694 \%$ \\
\hline$-0,574 \%$ & $0,207 \%$ & $-3,397 \%$ & $-4,634 \%$ & $18,120 \%$ & $12,485 \%$ \\
\hline
\end{tabular}

Table 7a. Correlation matrix (monthly returns 2008-2013)

\begin{tabular}{lcccccc}
\hline & MIV & LMI & MSEM & MSWO & EMBI+ & Blended \\
\hline MIVs & 1,000 & 0,613 & 0,676 & 0,622 & 0,597 & 0,668 \\
LMI & & 1,000 & 0,880 & 0,823 & 0,809 & 0,894 \\
MSEM & & & 1,000 & 0,854 & 0,788 & 0,903 \\
MSWO & & & & 1,000 & 0,659 & 0,910 \\
EMBI+ & & & & & 1,000 & 0,911 \\
Blended & & & & & & 1,000 \\
\hline
\end{tabular}

Table 7b. Correlation matrix (monthly returns 2013-2017)

\begin{tabular}{lcccccc}
\hline & MIV & LMI & MSEM & MSWO & EMBI+ & Blended \\
\hline MIVs & 1,000 & 0,178 & 0,503 & 0,344 & 0,324 & 0,395 \\
LMI & & 1,000 & 0,619 & 0,324 & 0,650 & 0,676 \\
MSEM & & & 1,000 & 0,529 & 0,676 & 0,766 \\
MSWO & & & & 1,000 & 0,211 & 0,507 \\
EMBI+ & & & & & 1,000 & 0,950 \\
Blended & & & & & & 1,000 \\
\hline
\end{tabular}

Table 7c. Correlation matrix (monthly returns 2008-2017)

\begin{tabular}{lcccccc}
\hline & MIV & LMI & MSEM & MSWO & EMBI+ & Blended \\
\hline MIVs & 1,000 & 0,524 & 0,640 & 0,558 & 0,540 & 0,609 \\
LMI & & 1,000 & 0,838 & 0,741 & 0,776 & 0,850 \\
MSEM & & & 1,000 & 0,805 & 0,765 & 0,869 \\
MSWO & & & & 1,000 & 0,564 & 0,793 \\
EMBI+ & & & & & 1,000 & 0,950 \\
Blended & & & & & & 1,000 \\
\hline
\end{tabular}

Table 8. Spanning tests

\begin{tabular}{ccc}
\hline LR Test & Wald test & LM test \\
\hline 38.518 & $2008-2013$ \\
$(0.000)$ & 52.055 & 29.295 \\
& $(0.000)$ & $(0.000)$ \\
\hline 11.652 & $2013-2017$ & 9.216 \\
$(0.000)$ & 27.808 \\
$(0.000)$ & $(0.007)$ \\
\hline \multicolumn{3}{c}{$2008-2017$} \\
\hline
\end{tabular}

$P$-Value are in brackets

\section{Conclusion}

Microfinance has become established as an attractive investment theme in recent years. The initial public offering of microfinance institutions raised much criticism, seeing in this economic model change a social mission drift of these originally socially-driven companies. However, raising money via capital markets could be beneficial to microfinance.

This article aims at examining whether investing in microfinance is an opportunity for international investors. More precisely, we study the performance of microfinance investment vehicles invested mainly in debt instruments. Despite a significant currency risk, we find that it is useful for investors to own a share of a portfolio consisting of MIVs from a diversification perspective: the integration of microfinance assets improves the efficient frontier. However, it should be noted that microfinance investment vehicles do not outperform the bond asset classes. We were also able to see a reduction of the performance during the end of our study period. The emergence of political risk and the increased default risk in some regions probably contributed to this evolution. 
Lastly, we should bear in mind that microfinance has a double bottom line: maximizing its financial performance, as well as its social performance. In the light of the findings of various studies analyzing the performance of microfinance assets, these results may encourage managers of socially responsible funds to invest in listed microfinance institutions. These asset managers could integrate microfinance companies as a satellite in core-satellite approach.

\section{References}

Becker, P. M. (2010). Investing in microfinance. Gabler Research. https://doi.org/10.1007/978-3-8349-8926-0

Brau, J. C., \& Woller, G. M. (2004). Microfinance: A Comprehensive Review of the Existing Literature. Journal of Entrepreneurial Finance and Business Ventures, 9(1), 1-26.

Brière, M., \& Szafarz, A. (2015). Does Commercial Microfinance Belong to the Financial Sector? Lessons from the Stock Market. World Development, 67, 110-125. https://doi.org/10.1016/j.worlddev.2014.10.007

CGAP. (2010). Microfinance Investment Vehicles Disclosure Guidelines. World Bank, Washington, DC.

Christen, R. P. (2001). Commercialization and mission drift: the transformation of microfinance in Latin America. CGAP: Occasional Paper No. 5.

Daher, L., \& Le Saout, E. (2013). Microfinance and Financial Performance. Strategic Change, 22(1-2), 31-45. https://doi.org/10.1002/jsc.1920

Daher, L., \& Le Saout, E. (2017). Performance of listed microfinance institutions. Strategic Change, 26(1-2), 145-158. https://doi.org/10.1002/jsc. 2117

De Lorenzo, M. C. (2011). Microfinance Investment Funds - An analysis of Profitability. Ibidem-Verlag.

De Mariz, F., Glisovic, J., González, H., \& Saltuk, Y. (2013). Volume Growth and Valuation Contraction Global Microfinance Equity Valuation Survey 2012. JP Morgan Global Equity Research, New York.

De Mariz, F., Reille, X., \& Rozas, D. (2012). Discovering limits: Global microfinance valuation survey 2011. JP Morgan Global Equity Research, New York.

Dieckmann, R. (2007). Microfinance: An emerging investment opportunity. Deutsche Bank Research.

Dominice, R., Holmegaard, M. P., \& Narayanan, R. (2014). 10-year track record outperforming mainstream asset classes. Syminvest Working paper.

Halpern, S. (2000). Microfinance in the New Millenium Efficiency, Customer Satisfaction, and Commercialization of Microfinance Institutions. Microfinance Network, Washington DC, USA.

Huberman, G., \& Kandel, S. (1987). Mean-variance spanning. Journal of Finance, 42(4), 873-888. https://doi.org/10.1111/j.1540-6261.1987.tb03917.x

Hudon, M., \& Ashta, A. (2013). Fairness and microcredit interest rates : from Rawlsian principles of justice to the distribution of the bargaining range. Business Ethics: A European Review, 22(3), 277-291. https://doi.org/10.1111/beer.12026

Janda, K., \& Svárovská, B. (2010). Investing into microfinance. Journal of Business Economics and Management, 11(3), 483-510. https://doi.org/10.3846/jbem.2010.24

Janda, K., \& Svárovská, B. (2012). Suitability of Microfinance as an Investment Option. CERGE-EI Working Paper Series No. 470. https://doi.org/10.2139/ssrn.2175342

Kan, R., \& Zhou, G. (2012). Tests of mean-variance spanning. Annals of Economics and Finance, 13, 145-193.

Khavul, S. (2010). Microfinance: creating opportunities for the poor? Academy of Management Executive, 24(3), 58-72. https://doi.org/10.5465/AMP.2010.52842951

Le Saout, E. (2005). Indice, Mon Bel Indice : Dis-Moi Qui Est Le Plus Performant - Le cas des indices éthiques. Banque et Marchés, 74, 24-31.

Le Saout, E., \& Daher, L. (2016). The efficiency of listed microfinance institutions. 4th International Symposium in Computational Economics and Finance, Paris.

Ledgerwood, J. (1999). Microfinance Handbook: an Institutional and Financial Perspective. World Bank, Washington, DC.

Meehan, J. (2004). Tapping the Financial Markets for Microfinance: Grameen foundation USA's promotion of this emerging trend. Working Paper Series Grameen Foundation USA.

Morduch, J. (2000). The microfinance schism. World Development, 28(4), 617-629. https://doi.org/10.1016/S0305-750X(99)00151-5 
Oehri, O., \& Fausch, J. (2008). Microfinance Investment Funds - Analysis of Portfolio Impact. University of Liechtenstein, Gevena papers on Inclusiveness No. 6, World Microfinance Forum Geneva.

Roon (de), F., Nijman, T., \& Werker, B. (2001). Testing for mean-variance spanning with short sales constraints and transaction costs: the case of emerging markets. Journal of Finance, 56(2), 721-742. https://doi.org/10.1111/0022-1082.00343

Swanson, B. (2008). The role of International Capital Markets in microfinance. In Microfinance - Emerging Trends and Challenges. Ed. S. Sundaresan, 25-45. https://doi.org/10.4337/9781848445178.00007

Appendix

Table A. Components of Microfinance funds portfolio

\begin{tabular}{lc}
\hline Name & Entry \\
\hline Azure Global Microfinance & January 2012 \\
BBVA Codespa Microfinanzas & January 2008 \\
Capital Gestion Microfinance & October 2012 \\
Dual Return Fund - Vision Microfinance & January 2008 \\
Dual Return Fund - Vision Microfinance Local Currency & September 2010 \\
Emf Microfinance Fund & December 2008 \\
Erste Responsible Microfinance & December 2008 \\
Etimos Fund - Global Microfinance & July 2011 \\
Finethic Microfinance SCA & January 2008 \\
IIV Microfinanzfonds & Dec 2011 \\
KCD Mikrofinanzfonds & April 2009 \\
Luxembourg Microfinance and Development Fund & May 2010 \\
ResponsAbility Global Microfinance Fund & January 2008 \\
ResponsAbility SICAV (Lux) Mikrofinanz-Fonds & January 2008 \\
ResponsAbility SICAV (Lux) Microfinance Leaders & January 2008 \\
Saint-Honore Microfinance & January 2008 \\
Tokio Marine Daiwa Microfinance & April 2011 \\
Triodos SICAV II Microfinance & May 2009 \\
Wallberg Global Microfinance & December 2008 \\
\hline
\end{tabular}

\section{Copyrights}

Copyright for this article is retained by the author(s), with first publication rights granted to the journal.

This is an open-access article distributed under the terms and conditions of the Creative Commons Attribution license which permits unrestricted use, distribution, and reproduction in any medium, provided the original work is properly cited. 